\title{
The Adoption of Environmental Management System in Malaysia's Manufacturing Organizations
}

\author{
H. H. Low, O. K. Tan, S. L. Choi, and A. R. Rabeatul Husna
}

\begin{abstract}
Environmental management system, EMS has been the most researched theme of late. Proponents of EMS claimed that EMS brings much benefit to organizations. However, most of the organizations are slow to adopt this new form of management. Employee's resistance to change has been cited by many as one of the impediments to EMS adoption. As such, employee's views must be sought to ensure successful adoption of EMS. 214 manufacturing firms were surveyed using the modified PORC instruments to access employee's perceptions of firm's implementation of EMS. Factor analysis conducted yielded four factors i.e. work impact, management support, implementation support and EMS survival; were found to have significant contribution towards EMS adoption. Recommendations were also provided to ensure better adoption of EMS in manufacturing firms.
\end{abstract}

Index Terms-Adoption, employee's perception, EMS, ISO14001.

\section{INTRODUCTION}

In June 1992, 170 countries converged at Rio de Janeiro to mark the beginning of the global efforts to manage the world's environment under the United Nations Conference on Environment and Development (UNCED) platform (Culley, 1998) [1]. However, it wasn't until the Third Conference of the Parties to the United Nations Framework Convention of Climate Change in 1997 or the Kyoto Protocol; that some tangible outcome to sustainable development was introduced (Böhringer \& Vogt, 2004) [2]. These meetings resulted in organizations globally began incorporating environmental management as they anticipate a multitude effects of stringent legislation; market driven for environmental friendly products; and escalation of concern from stakeholders related to environmental issues (Strachan, 1996; Maliah \& Nik Nazli, 2002) [3], [4]. Indeed, studies pertaining environmental management system (EMS) using ISO 14001 as the criterion found that organizations stand to gain from its implementation and usage (Briggs, 2007; Mori \& Welch, 2008; Goh, Suhaiza \& Nabsiah, 2006; Fortunski, 2008; Matuszak-Flejszman, 2009; Haslinda, Abdullah \& Chan, 2010; To, Lee \& Yu, 2011; de Vries, Bayramoglu \& Van der Wiele, 2012) [5]-[12].

However, not many organizations are convinced of this realignment. ISO 14001 which was published on 1

Manuscript received August 29, 2013; revised November 2, 2013.

H. H. Low, O. K. Tan and S. L. Choi are with the Management Department, Universiti Teknologi Malaysia (e-mail: h2low@management.utm.my, oktan@utm.my, slchoi@utm.my)

A. R. Rabeatul Husna is with the Human Resource Development Department, Universiti Teknologi Malaysia (e-mail husna@management.utm.my).
September 1996 and later revised in 2004 (Blackman \& Guerrero, 2012) [13] has only an estimated endorsement of more than 250,000 companies in over 130 countries (Boiral \& Henri, 2012; Curkovic \& Sroufe, 2011) [14], [15]. In Malaysia, at the end of 2011, only 1934 companies are registered with ISO 14001certification [16]. This dismal figure is partly influenced by the fact that organizational change is essential for EMS adaptation (Cassells, Lewis \& Findlater, 2012) [17]. Employees' resistance; readiness of organizational to change and perceived transformation as unnecessary are found to be the main impediment to ISO 14001 certification (Zutshi, Sohal \& Adams, 2008; Cassells, Lewis \& Findlater, 2012) [17], [18].

In order to facilitate the adoption of EMS, environment champions must have the necessary tools to prepare organizations to accept this change. Since, organization change will not happen without the conviction of its members, measuring its members' perspectives about EMS is necessary for successful EMS adoption. This study seeks to undertake this task using the modified construct of perceived organizational readiness for change (PORC) as backdrop. PORC is developed based on the assumption that for organization to adopt change successfully, its employees' must be persuaded, convinced and embraced those changes (Armenakis, Harris \& Mossholder, 1993)[19]. As employee' commitments are necessary ingredient for successful EMS adoption, the use of PORC as basis to measure organization's adoption towards EMS is thus justified.

\section{LITERATURE REVIEW}

\section{A. Environmental Management System, EMS}

EMS is "that aspect of an organization's overall management structure that addresses the immediate and long-term impact of its products, services, and processes on the environment" (Hemenway, 1995, pp. 4) [20]. It begins fragmented with formation of the British Standard 7750 (BS7750) by the UK and later the Eco-management and Audit System (EMAS) developed by the European Commission (EC) to provide a standard that could be accepted internationally (Ritchie \& Hayes, 1998) [21]. However, both of these standards failed the test of harmonizing industries differences in environmental management; as well as providing an effective tool for managers to protect their organizations against potential negative impact on trade and commerce while achieving their environmental objectives (Ritchie \& Hayes, 1998) [21]. These shortcomings must be address in order to induce organizations to manage their environment responsibly. Hence, the Strategic Advisory Group on the Environment 
(SAGE) was established by the International Standard of Organization (ISO) to make recommendations for an international environmental standard in 1991. The net result; after much deliberation and difficult international consensual process based on industry experience with EMSs; is the introduction of the ISO 14000 series in 1993, with the dual aims of helping organizations globally to become environmental friendly and sustainable [22].

\section{B. Impact of ISO 14001}

The main advantage derived from an ISO 14001 certification is the ease of international business transaction due to the removal of trade barriers (Mori \& Welch, 2008; Schylander \& Martinuzzi, 2007) [6], [23]. Others include changes in business processes and greater market share (Samuel \& Bo, 2007; Gonzalez-Benito \& Gonzalez-Benito, 2008) [24], [25]. Paradoxically, managers assume these changes are customary while employees may trend this new ground with caution (Smith, 2005) [26]. Some see this as an opportunity to better themselves (Bosse, Breure \& Spies, 2006) [27]; while others responded with fear, resistance, anger, frustration and confusion of the unknown and; some out of the augmentation of responsibilities and workload that EMS brings (Bovey \& Hede, 2001; Ayse, 2003; Bat \& Varda, 2003; Pun, Fung \& Wong, 1998) [28]-[31]. Though scholars have generally agreed that there are four main variables which influenced the successful implementation of ISO14001 i.e. feedback and review; employee empowerment; rewards; and management commitment (Nalini \& Daily, 2004) [32]; chief amongst them are the lack of resistance from employees (Ford, Ford \& McNamara, 2002; Calabrese, 2003) [33], [34].

\section{Perceived Organizational Readiness for Change, PORC}

PORC has been used in mapping change since the late 1970s. Authors such as Cunningham et al. (2002) [35]; and Lehman, Greener and Simpson (2002) [36] suggested that organization must be ready before change could be instituted. We expanded this construct to include the perspective of employees as proposed by Armenakis, Harris and Mossholder (1993) [19]; and Jansen (2000) [37] since any evaluation of change must include perspectives of those who are most affected i.e. the employees. The use of employees' perspectives as a construct to measure EMS adoption is more consistent and distinct as the present measurement of "organizational adoption" is rather vague (Cinite, Duxbury \& Higgins, 2009) [38]. For example, Armenakis, Harris and Mossholder (1993) [19] refers this term to connote structural attributes of organizations while Cunningham et al. (2002) [35] suggest that it is the employees' conviction. Moreover, most studies seems to have restrict their analysis from the perspective of change agents which usually, but not essentially, that of an EMS champion. Additionally, Nalini and Daily (2004) [32] proposed that success of any new management system's success rests on the way employees perceived and responded to it.

\section{Methodology}

The entire manufacturing firms in Johor Bahru district, which includes industrial estates in Pasir Gudang, Senai, Tanjung Langsat and Tebrau, make up the population of this study. They were identified from Johor Industry Guide, which was published by Johor Technopark Sdn. Bhd. There were 486 manufacturing firms found from the above mentioned locations. We used Krejcie and Morgan's (1970) [39] formula with 5\% margin of error for determining sample size. This was deemed appropriate by Bartlett, Kotrlik, and Higgins (2001) [40] as it concurs with Cochran's (1977) [41] sample size formula for both continuous and categorical data. Hence, the sample size of this study was 214 organizations. To ensure that various levels of the employees' perceptions are obtained from each of the organization surveyed, stratified sampling technique was employed since this method is able to provide the "inclusion of diverse elements of the population" (Gay, 1996, pp. 25) [42].

Factor analysis using Principal Components Analysis with a Varimax rotation followed by Confirmatory Factor Analysis (CFA) was utilized to factor structure our measures. Only factor with item loading of 0.7 or greater was retained in agreement with proposal made by Howell, Shea and Higgins (2005) [43]. To ensure individual reliability of the factors generated from the earlier factor analysis and CFA treatment, we opted for the usual rule of thumb that items should score greater than 0.7 on the Cronbach's alpha measure of internal consistency (Barclay, Higgins \& Thompson, 1995) [44].

\section{RESUlts}

The 507 prospective organizations surveyed in this study, only 346 organizations responded, resulting in a response rate of $68.2 \%$.

Four factors emerged from factor analysis using the Principal Component Analysis extraction and Varimax with Kaizen Normalization rotation method. These four factors which were named work impact, management support implementation support, and EMS survival were later subjected to a CFA using AMOS and items with factor loading less than 0.7 were dropped as they were deemed unreliable. Each questionnaires assigned to the four factors has a 5-points agreement scale with 5 being most agreeable. Results from analyses carried out were shown in Table I.

In 'Work Impact' factor, all three items loading on this factor are related to the impact of EMS adoption onto employee's workload. Higher mean score indicated employees' perceived the implementation of EMS had adverse effect on their workload. The overall mean for this factor is 3.93 indicating the adoption of EMS has an unfavorable effect on work. Crobanch's alpha is 0.88 which means that the scale is reliable.

The five items which loaded on the 'Management Support' factor are all related to the support employees received from their organization about EMS. Employees are encouraged about EMS when their organization provides the necessary resources, awareness program and senior management commitment to EMS implementation. Overall mean score of 3.58 was recorded for this factor indicating a moderate level of implementation as viewed by the employees. Crobanch's alpha for this scale is 0.91 and it is deem reliable. 
'Implementation Support' factor has three items loading and they comprises of availability of platform to share experiences and knowledge as well as assistance during EMS implementation. Employees tend to perceive their organization as adopting EMS if people willingly share their experience and help is always available when they needed it. Crobanch's alpha for this scale is 0.92 which again is deem reliable. With a score of 3.25 for the overall mean of this factor, the implementation related to this factor is considerable moderate in the eyes of the employees.

The last, 'EMS Survival' factor consists of six items and they deals with the existence of EMS in the long term. Often, when the novelty of the system is over, it is discarded in favor of the "trendier" system. Overall mean score of 3.95 was recorded indicating employees' viewed EMS adoption as a long term affair and there must be a will to continually improve it. Crobanch's alpha for this scale is 0.87 signifying reliability in this scale.

\begin{tabular}{|c|c|c|c|c|c|c|}
\hline Organizational adoption of EMS & Mean & SD & 1 & 2 & 3 & 4 \\
\hline \multicolumn{7}{|c|}{ Work Impact (1) } \\
\hline $\begin{array}{l}\text { The EMS process does not involve the phasing out of old duties, and } \\
\text { the employee is expected to do both the old and the new duties. }\end{array}$ & 3.98 & 0.56 & 0.889 & & & \\
\hline $\begin{array}{l}\text { Workloads do not permit people to get involved in the EMS } \\
\text { initiatives. }\end{array}$ & 3.90 & 0.71 & 0.707 & & & \\
\hline $\begin{array}{l}\text { People are discouraged from saying 'no' to work - even when the } \\
\text { assigned task is not a priority. }\end{array}$ & 3.90 & 0.67 & 0.734 & & & \\
\hline \multicolumn{7}{|c|}{ Management Support (2) } \\
\hline $\begin{array}{l}\text { My company provides human resources (people, manpower) for } \\
\text { EMS. }\end{array}$ & 3.73 & 0.51 & & 0.712 & & \\
\hline $\begin{array}{l}\text { My company has defined the roles and responsibilities of its } \\
\text { emplovees in adopting EMS. }\end{array}$ & 3.69 & 0.68 & & 0.737 & & \\
\hline $\begin{array}{l}\text { My company has activities to enhance employee awareness of their } \\
\text { roles and responsibilities with regards to EMS. }\end{array}$ & 3.47 & 0.65 & & 0.754 & & \\
\hline $\begin{array}{l}\text { Senior managers in my company are involved in communicating the } \\
\text { importance of EMS in their departments. }\end{array}$ & 3.36 & 0.78 & & 0.777 & & \\
\hline $\begin{array}{l}\text { Senior managers in my company should be seen to be involved in the } \\
\text { various activities related to EMS. }\end{array}$ & 3.58 & 0.75 & & 0.702 & & \\
\hline \multicolumn{7}{|c|}{ Implementation Support (3) } \\
\hline $\begin{array}{l}\text { There exist on-going supports in the form of a help-desk for the EMS } \\
\text { coordinators in my company. }\end{array}$ & 2.83 & 0.57 & & & 0.732 & \\
\hline $\begin{array}{l}\text { My company establishes a network of EMS which can facilitate } \\
\text { sharing of knowledge and experiences across all departments. }\end{array}$ & 3.15 & 0.65 & & & 0.787 & \\
\hline $\begin{array}{l}\text { My company provides assistance to implement the various elements } \\
\text { of EMS. }\end{array}$ & 3.76 & 0.89 & & & 0.877 & \\
\hline \multicolumn{7}{|c|}{ EMS Survival (4) } \\
\hline EMS must be seen as a long term measure. & 4.08 & 0.75 & & & & 0.837 \\
\hline $\begin{array}{l}\text { Benchmarking must be done with industry of the same sectors in } \\
\text { order to learn from their approaches and avoid repeating the same mistakes. }\end{array}$ & 4.39 & 0.67 & & & & 0.746 \\
\hline $\begin{array}{l}\text { There is recognition of initiatives implemented by individual } \\
\text { department to reduce their impact on the environment in my company. }\end{array}$ & 3.65 & 0.89 & & & & 0.764 \\
\hline $\begin{array}{l}\text { There is recognition of progress made to reduce environment impact } \\
\text { in my company/department. }\end{array}$ & 3.74 & 0.86 & & & & 0.747 \\
\hline My company established program for periodic internal audit. & 3.89 & 0.63 & & & & 0.830 \\
\hline $\begin{array}{l}\text { My company's internal audit programs show continuous } \\
\text { improvement. }\end{array}$ & 3.86 & 0.53 & & & & 0.753 \\
\hline Cronbach's alpha & & & 0.88 & 0.91 & 0.92 & 0.87 \\
\hline Overall mean & & & 3.93 & 3.58 & 3.25 & 3.95 \\
\hline
\end{tabular}

\section{DISCUSSION AND CONCLUSION}

This study set out to develop a behavior anchored measure of organizational adoption of EMS in Malaysia SMEs. It is a multidimensional measure that targets employees' views of organizational implementation of EMS. Contextually, it is unique since it takes into consideration organization's internal views of EMS implementation rather than instrument which utilizes exogenous dimension. As such, we are able to provide opportunity for organization's to review actions that may require more attention in implementing their EMS endeavor.

The findings of this study imply that organizations need to provide the necessary support, considering their employees' workload and to ensure EMS endurance. These findings are consistent with the findings of other authors such as Kavanagh and Ashkanasy (2006) (leadership) [45]; Duck (2001) [46]; Kotter and Cohen (2002) (immediate 
supervision's commitment) [47]; Zutshi, Sohal and Adams (2008) (sufficient human resource capabilities) [18]; Cinite, Duxbury and Higgins (2009) (organizational structure) [38].

Findings from this study also send an important message that:

1) The implementation of EMS in Malaysia SMEs always resulted in augmentation of employee's workload. In adding new duties to the existing ones, discouraging employees from saying 'no' to work and the already heavy workloads experienced by employees will hinder EMS implementation and dampened employees from getting involve in EMS. Observations by past scholars such as Bovey and Hede (2001); Ayse (2003) [28], [29] suggest a link between increased workloads and negative work behavior such as resistance, anger, frustration and confusion. Further evidence from Cinite, Duxbury and Higgins (2009) [38] work, indicated that employees are more willing to participate in organizational change if they perceived organization as being supportive and understanding of their plight. Hence, SMEs in Malaysia should take cue of their employees' workloads if EMS is to be implemented with vigor.

2) Commitment and support of senior management is imperative to EMS implementation. This is consistent with the findings of Sarkis and Sroufe (2004) and Zutshi and Sohal (2005) [48], [49]. Senior management must not only provide the necessary personnel, training, resources and budget; they should also communicate the importance of EMS in their department through hands-on involvement. In this way, employees are inspired to take up the challenge knowing that they have the full support of their managers.

3) EMS implementation is a continuous effort which required constant aid in the form of advice and knowledge sharing via the utilization of a help-desk or corporate repository system or communities of experts. This would avoid repeated pitfalls and duplication of unproductive efforts. Moreover, study also indicated that cumulative knowledge and well-established experience curve led to greater certainty and promotes new ideas and innovative environmental solutions (Karagozoglu \& Lindell, 2000) [50]. This was because a greater experience curve enables firms to process greater amount of information on environmental issues hence enabling innovativeness. As such, coordinated efforts to established network to facilitate the sharing of experiences gained in departmental EMS adoption would help to ensure better result from the EMS exercise.

4) Introduction of EMS as short-term measures in order to gain entry into global market will not ensure environmental sustainability. Study by Yin and $\mathrm{Ma}$ (2009) [51] on manufacturing firms in China, for example found that ISO 14001 certification was merely used as gateway for entry into advance market rather than the genuine concern to improve environmental performance. In the same vein, Boiral (2007) [52] concluded that the daily operations of firms appeared isolated from the remedies suggested in the ISO 14001 system. Hence, the environmental initiatives must be seen as a long term investment and the extensive benefits of this initiative can only be realized much later. This view was supported by Curkovic and colleagues (2003) [53], where it was found that firm's environmental performance correlates positively with the longevity of the EMS implementation; with the longer, the higher impact.

It should be noted that most of the firms' surveyed in this study are related to export oriented business with the US and the ASEAN as their most popular destinations. The ISO14001's certification is widely acknowledged as one of the criteria for business transactions in these countries. Moreover, analysis of company profile showed that most of the respondents' firms $(65 \%)$ are foreign owned. Additionally, most of the Malaysian owned companies act as suppliers or sub-contractors for the core firms, which are foreign-owned and has been rather insistent in their environmental adoption. Thus, environmental friendly is important to ensure that Malaysia owned companies remain as core suppliers or sub-contractors to these firms.

There are also some limitations that could be taken by future researcher. This study did not address the stage of EMS implementation that a particular organization has gone through. Naturally, organizations with longer experience in ISO14001 will fare better in the adoption of EMS while the newly implemented are less prepared. Examining employees' perceptions from a snap short research like this is another limitation. This is because perceptions change with time. Thus, a longitudinal study could be explored to provide employees' views about their organization readiness over time.

\section{REFERENCES}

[1] W. C. Culley, Environmental and Quality Management System Integration, Florida: CRC Press Inc. Lewis Publishers, 1998.

[2] C. Böhringer and C. Vogt, "The dismantling of a breakthrough: The kyoto protocol as symbolic policy," European Journal of Political Economy vol. 20, no. 3, pp. 597-617, 2004.

[3] P. A. Strachan, "Achieving environmental excellence through effective teamwork," Team Performance Management an International Journal, vol. 2, no. 1, pp. 25-29, 1996

[4] M. Sulaiman and N. Nazli, "ISO 14001 and corporate performance: A survey of certified companies in Malaysia," International Islamic University Malaysia Management, vol. 21 no. 5, pp. 22-34, 2008.

[5] S. L. K. Briggs. (2007). Clarifying the Intent of ISO 14001, Quality Progress, Standards Outlook. [Online] Available: http://www.asq.org/quality-progress/2007/08/environmental-manage ment-and- sustainability/iso-14001-hits-10-year-mark.html.

[6] Y. Mori and E. W. Welch, "The ISO 14001 environmental management standard in Japan: results from a national survey of facilities in four industries," Journal of Environmental Planning and Management, vol. 51, no. 3, pp. 421-445, 2008.

[7] E. A. Goh, Z. Suhaiza, and A. W. Nabsiah, "A study on the impact of environmental management system (EMS) certification towards firms' performance in Malaysia Management of Environmental Quality," An International Journal, vol. 17, no. 1, pp. 73-93, 2006.

[8] B. Fortunski, "Does the environmental management standard ISO 14001 stimulate sustainable development? An example from the energy sector in Poland. Management of Environmental Quality," An International Journal, vol. 19, no. 2, pp. 204-212, 2008

[9] A. M. Flejszman, "Benefits of environmental management system in polish companies compliant with ISO 14001," Polish Journal of Environment Study, vol. 18, no. 3, pp. 411-419, 2009.

[10] Haslinda, Abdullah, and C. C. Chan, "The implementation of ISO 14001 environmental management system in manufacturing firms in Malaysia," Asian Social Science, vol. 6, no. 3, pp. 100-107, 2010.

[11] W. M. To, K. C. Lee, and T. W. Yu, "Benefits of implementing management system standards: A case study of certified companies in 
the Pearl River Delta, China," The TQM Journal, vol. 24, no.1, pp. $17-28,2012$

[12] H. J. de Vries, D. K. Bayramoglu, and T. V. der Wiele, "Business and environmental impact of ISO 14001," International Journal of Quality \& Reliability Management, vol. 29, no. 4, pp. 425-435, 2012

[13] A. Blackman and S. Guerrero, "What drives voluntary eco-certification in Mexico?" Journal of Comparative Economics, vol. 40, no. 2, pp. 256-68, 2012.

[14] O. Boiral and J. F. Henri, "Modeling the impact of ISO 14001 on environmental performance: A comparative approach," Journal of Environmental Management, vol. 99, pp. 84-97, 2012.

[15] S. Curkovic and R. Sroufe, "Using ISO 14001 to promote a sustainable supply chain strategy," Business Strategy and the Environment, vol. 20 pp. 71-93, 2011.

[16] ISO survey database. [Online] Available: http://www.iso.org

[17] Cassells, K. V. Lewis, and A. Findlater, "An exploration of ISO 14001 uptake by New Zealand firms," International Journal of Law and Management, vol. 54, no. 5, pp. 345-363, 2012.

[18] A. Zutshi, A. S. Sohal, and C. Adams, "Environmental management system adoption by government departments/agencies," International Journal of Public Sector, vol. 21, no. 5, pp. 525 -539, 2008.

[19] A. A. Armenakis, S. G. Harris, and K. W. Mossholder, "Creating readiness for organizational change," Human Relations, vol. 46, pp. $681-703,1993$

[20] C. G. Hemenway, What is ISO 14000? Questions and Answers, 2nd ed., Fairfax, Virginia: CEEM Information Services, 1995.

[21] I. Ritchie and W. Hayes, A guide to the implementation of the ISO 14000 Series on environmental management, Upper Saddle River, NJ: Prentice Hall PTR, Prentice-Hall, Inc., 1998

[22] ISO. (2005). The ISO Survey 2005, International Organization for Standardization. [Online] Available: http ://www.iso.org.iso/survey2005.pdf

[23] E. Schylander and A. Martinuzzi, "ISO 14001 - Experiences, effects and future challenges: A national study in Austria," Business Strategy and the Environment, vol. 16, no. 2, pp. 133-147, 2007.

[24] P. S. Samuel and E. Bo, "ISO14001 as a driving force for sustainable development and value creation," The TQM Magazine, vol. 19, no.5, pp. 468-482, 2007.

[25] J. G. Benito and O. G. Benito, "Operations management practices linked to the adoption of ISO 14001: An empirical analysis of Spanish manufacturers," International Journal of Production Economics, vol. 113, no. 1, pp. 60, 2008.

[26] I. Smith, "Continuing professional development and workplace learning 13 Resistance to change -recognition and response," Library Management, vol. 26, no. 9, pp. 519-522, 2005.

[27] G. Bosse, J. P. Breuer, and C. Spies, "The resistance to changing guidelines-what are the challenges and how to meet them," Best Practice and Research Clinical Anesthesiology, vol. 20, no. 3, pp. 379-395, 2006.

[28] W. H. Bovey and A. Hede, "Resistance to organizational change: the role of cognitive and affective processes," Leadership and Organization Development Journal, vol. 22, no. 8, pp. 372-382, 2001.

[29] S. Ayse, "Internal change agents' view of the management of change problem," Journal of Organizational Change Management, vol. 16, no. 5, pp. 480-496, 2003.

[30] S. D. G. Bat and Y. Varda, "Incumbent employees' resistance to implementing privatization policy," Journal of Economic Behavior and Organization, vol. 59, pp. 374-405, 2003.

[31] K. F. Pun, Y. K. Fung, and F. Y. Wong, "Identification of critical factors for total quality environmental management," in Proceedings of the 3rd Annual International Conference on Industrial Engineering Theories, Applications and Practice, Hong Kong, December 1998, vol. PN114, pp. 1-9.

[32] G. Nalini and B. F. Daily, "Motivating Employees for Environmental Improvement," Industrial Management and Data Systems, vol. 104, no. 4, pp. 364- 372, 2004.

[33] J. D. Ford, L. W. Ford, and R. T. McNamara, "Resistance and the background conversations of change," Journal of Organizational Change Management, vol. 15, no. 2, pp. 105-121, 2002.

[34] R. L. Calabrese, "The ethical imperative to lead change: overcoming the resistance to change," The International Journal of Educational Management, vol. 17, no. 1, pp. 7-13, 2003.

[35] C. E. Cunningham, C. A. Woodward, H. S. Shannon, J. MacIntosh, B. Lendrum, D. Rosenbloom, and J. Brown, "Readiness for organizational change: a longitudinal study of workplace, psychological and behavioural correlates," Journal of Occupational and Organizational Psychology, vol. 75, pp. 377-392, 2002.

[36] W. E. Lehman, K. J. M. Greener, and D. D. D. Simpson, "Assessing organizational readiness for change," Journal of Substance Abuse Treatment, vol. 22, pp. 197-209, 2002.

[37] K. J. Jansen, "The emerging dynamics of change: resistance, readiness, and momentum," Human Resource Planning, vol. 23, pp. 53-55, 2000.

[38] I. Cinite, L. E. Duxbury, and C. Higgins, "Measurement of Perceived Organizational Readiness for Change in the Public Sector," British Journal of Management, vol. 20, pp. 265-277, 2009

[39] R. V. Krejcie and D. W. Morgan, "Determining sample size for research activities," Educational and Psychological Measurement, vol 30, pp. 607-610, 1970

[40] J. E. Bartlett, J. W. Kotrlik, and C. C. Higgins, "Organizational research: Determining appropriate sample size in survey research information technology," Learning, and Performance Journal, vol. 19, no. 1, pp. 43-50, Spring 2001.

[41] W. G. Cochran, Sampling Techniques, Third Edition, New York: John Wiley and Sons, Inc. 1977

[42] L. R. Gay, Educational research: Competencies for analysis and application, Upper Saddle River, NJ: Merrill, 1996, ch 3.

[43] J. M. Howell, C. M. Shea, and C. A. Higgins, "Champions of product innovations: defining, developing and validating a measure of champion behavior," Journal of Business Venturing, vol. 20, pp. 641-661, 2005

[44] D. Barclay, C. A. Higgins, and R. L. Thompson, "The partial least squares (PLS) approach to casual modeling: personal computer adoption and use as an illustration," Technology Studies, vol. 2, pp. 285-309, 1995.

[45] M. H. Kavanagh and N. M. Ashkanasy, "The impact of leadership and change management strategy on organizational culture and individual acceptance of change during a merger," British Journal of Management, vol. 17, pp. 81-103, 2006.

[46] J. D. Duck, The Change Monster: The Human Forces that Fuel or Foil Corporate Transformation and Change, New York: Crown Business, 2001.

[47] J. P. Kotter and D. S. Cohen, The Heart of Change, Boston, MA: Harvard Business School Press, 2002.

[48] J. Sarkis and R. Sroufe, "Strategic sustainability: The state of the art in corporate environmental management systems," Greener Management International, no. 46, pp. 5-9, 2004.

[49] A. Zutshi and A. S. Sohal, "Integrated management system: the experiences of three Australian organizations," Journal of Manufacturing Technology Management (formerly Integrated Management Journal), vol. 16, no. 2, pp. 211-32, 2005.

[50] N. Karagozoglu and M. Lindell, "Environmental management: Testing the win-win model," Journal of Environmental Planning and Management, vol. 43, no. 6, pp. 817-829, 2000.

[51] H. T. Yin and C. B. Ma, "International integration: a hope for a greener China?" International Marketing Review, vol. 26, no. 3, pp. 348-67, 2009.

[52] O. Boiral, "Corporate greening through ISO 14001: a rational myth?" Organization Science, vol. 18, no. 1, pp. 127-46, 2007.

[53] S. Curkovic, R. Scroufe, and S. Melnyk, "Identifying the factors which affect the decision to attain ISO 14000," Energy, vol. 30, issue 8, pp. 1387-1407, Elservier Science Ltd, pp. 1-24, 2004

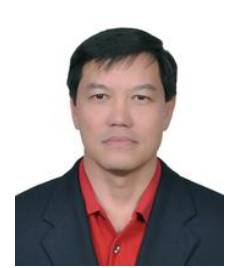

H. H. Low was born in Malaysia in November 1963 His early education is in St. Andrew's School and proceeds to Universiti Teknologi Malaysia in Skudai, Johor for his post graduate study. Low gained his $\mathrm{PhD}$ in management specializing in university commercialization on October 2011. He begins his career as an Education Officer with the Malaysia Ministry of Education in 1987 followed by a short stint of 5 years in the Courseware Development before ended up being a University Lecturer at Universiti Teknologi Malaysia in Skudai, Malaysia. $\mathrm{He}$ has published in various journals including articles on university commercialization and knowledge economy with the International Journal of Economic Research, Archives Des Sciences as well as the Journal of Basic and Applied Scientific Research. His current interest is in the area of knowledge and sustainability management. Dr. Low is a member of the Malaysia Institute of Management and the Vice President for the Johor Aids and Action Research Society. Dr. Low was awarded with the Excellent Service Award by the university twice in 2002 and 2010. 